\title{
Breaking the rules: success and failure in groupware-supported business process reengineering
}

\author{
Alan R. Dennis ${ }^{\mathrm{a}, *}$, Traci A. Carte ${ }^{\mathrm{b}}$, Gigi G. Kelly ${ }^{\mathrm{c}}$ \\ ${ }^{a}$ Accounting and Information Systems Department, Kelley School of Business, Indiana University, Bloomington, IN 47405, USA \\ ${ }^{\mathrm{b}}$ Division of MIS, Michael F. Price College of Business, University of Oklahoma, Oklahoma City, OK, USA \\ ${ }^{\mathrm{c}}$ School of Business Administration, College of William and Mary, Williamsburg, VA, USA
}

Accepted 3 July 2002

\begin{abstract}
In the information economy, businesses are changing more often and more rapidly than ever before. The lessons learned from a decade of business process reengineering (BPR) research may provide insights to researchers and managers trying to understand and successfully navigate these changes. This paper examines the successes and failures of groupware-supported BPR processes in four organizations. Two were successful and two were failures. Groupware allowed certain tasks to be performed faster, added structure to the BPR process and facilitated participation by more people. The key difference between the successful and the unsuccessful cases was when and how senior management was involved.
\end{abstract}

(C) 2002 Elsevier Science B.V. All rights reserved.

Keywords: Group support systems; Business process reengineering; Case study

\section{Introduction}

With the rise of e-commerce, enterprise systems, customer relationship management and other technology-enabled new business practices, businesses now face major changes in much shorter time periods. The challenges of the new Internet economy may offer an opportunity to apply the lessons learned from a decade of business process reengineering (BPR) efforts, which likewise sought ways to manage major change $[5,20,28]$. Notwithstanding the hype and the many reported failures, reengineering efforts of the

\footnotetext{
* Corresponding author.

E-mail address: ardennis@indiana.edu (A.R. Dennis).
}

1990s were often focused on the same areas now linked to e-commerce disasters, such as poor inventory management, fulfillment or shipping processes [28]. These are not technology problems. These are process problems - problems that result from a failure to recognize that process excellence [28] or "process think" [20] is necessary to make e-commerce sites succeed. Here is where BPR knowledge can help.

BPR has been defined as a fundamental redesign of business processes to achieve dramatic improvements in critical areas such as cost, quality, service and speed [22]. In its classic form, BPR had at least three key elements or "rules" [22,25]. First, the goal was large, dramatic improvements, not incremental or marginal improvements. Second, because the changes were radical, there was an emphasis on "clean-slate" 
changes, where current processes were ignored or thrown away. Third, the BPR project typically was driven from the top of the organization using small teams of top managers.

BPR has been a high-risk, high-reward proposition. BPR has the potential to significantly improve business performance, but as many as $70 \%$ of all BPR projects have failed [25]. Many reasons have been given for BPR failure $[3,7,23,25]$. Some projects did not follow the clean-slate approach and therefore died off before implementation because of the high cost and lengthy time spent in analysis. Others died in the implementation phase (or shortly thereafter), because the radical, clean-slate approach caused important factors to be overlooked or top management teams neglected to involve the middle managers charged with implementation and therefore they were not committed to the changes.

Several articles suggest that a groupware-based BPR approach may mitigate some of these causes for failure. Groupware may significantly reduce the time and cost of the analysis phases and, by enabling more middle managers to participate in the analysis and design, may ease some of the implementation issues $[10,13,48]$.

In this study, we sought to address two questions: Do the classic BPR rules still apply in a groupwaresupported BPR environment? And, if not, what is a "best practice" groupware BPR process? In the following sections, we explore the interactions between BPR in its traditional sense and groupware-supported BPR in practice. Then, we describe four case studies using groupware in varying ways to facilitate the BPR effort. We conclude with an analysis of the case outcomes and identify factors in the groupware BPR process we believe led to success and describe a groupware BPR "best practice."

\section{Previous research}

Some BPR researchers have focused on key factors in the BPR process that enabled a successful outcome. As mentioned, classic studies (i.e., Ref. [25]) suggested that BPR processes could only succeed if the focus was on radical change, the analysis proceeded from a clean slate and top management drove the process. Because then, examples of successful proj- ects have sometimes challenged these factors [2]. What is known about successful BPR processes is presented in the following sections, followed by the potential impact of groupware support.

\subsection{Radical change}

Classic BPR theorists were adamant that the fundamental focus of BPR is radical change $[23,25,26]$. Incremental improvements are to be avoided because marginal improvements generally make things worse by complicating simple processes [25]. Incremental improvements can also psychologically lock organizations into the old processes [25]. Recent empirical results suggest that BPR can succeed with an evolutionary implementation plan, but the design effort must be radical [27].

In some cases, this emphasis on radical change has been linked to failure. Because people interpret the word "radical" in different ways, it is important that managers clearly communicate the level of desired change [7]. Depending on of the level of change desired, ideas might be too radical or not radical enough $[6,25]$.

\subsection{Clean-slate analysis}

Because of their focus on radical change, proponents of classic BPR have also remained adamant about a "clean-slate" approach in which no analysis is done of current processes $[23,25,26]$. They argue that the lack of a clean slate can lead to incremental rather than radical innovation, because the new design remains anchored on the current processes rather than being free to focus on the ideal situation. Hammer argues, "(A)nalysis is a profound waste of time. If you know you are going to start over, what is the value of creating this exhaustive documentation?" [23,p.44g]; all that is needed is a brief understanding of current processes. Recent empirical results suggest that detailed analysis of current processes contributes little to the ultimate success of the BPR project [43].

Proponents of the clean-slate approach argue that modeling of current processes can result in prolonged analysis or "analysis paralysis" [23]. However, the counterargument is that the clean-slate approach is often expensive and time consuming to implement [9]. A survey of 47 "successful" organizations iden- 
tified modeling of current processes as a "best practice" leading to success [4]. In these cases, process modeling created a shared understanding of the current processes, helped ensure that nothing was "lost," enabled the organization to identify and keep the best parts of the process, created a fact-based baseline against which to compare the new processes and laid the groundwork for an implementation plan.

\subsection{Top management teams}

Proponents of classic BPR also have remained adamant about the need for a top-down driven approach $[23,25,26]$. Middle managers are to be avoided, because they lack the vision and authority to implement BPR and have much invested in the current process. Projects should be conducted by teams of 5-10 members, typically composed of senior managers inside the organization and a few outsiders (e.g., information systems staff and consultants) [25]. Top managers on the team must drive the change by providing vision [33]. The other insiders on the team should understand the process (or parts of it) but not be too close to it or they will tend to reinvent the same process. The outsiders bring objectivity, because they do not understand the current process. Therefore, they are not afraid to ask naive questions that shatter assumptions $[19,45]$.

However, despite the resolute objections of classic BPR proponents, there is evidence that it is important to include knowledge and build support from the bottom $[3,4,9,40]$. In this way, those who understand it, not senior managers unfamiliar with it, do the detailed design of work.

\subsection{Groupware-supported BPR}

Groupware has emerged as an important enabling technology for a variety of team-based processes [35] and it has been used in several BPR projects with some success $[10,13,49]$. With the form of groupware used in these prior studies (and those reported here), group members worked together in the same room at the same time and used computers to interact and exchange ideas instead of and in addition to discussing ideas verbally. This form of groupware provides a package of three components [35]. The first is a meeting room that provides networked computer workstations to all participants, plus a large-screen video projection system that acts as an electronic blackboard. The second is special purpose software that enables participants to communicate anonymously and in parallel and to use formal decisionmaking techniques such as rating, ranking and multicriteria decision-making. The third component is the facilitator whose role may include assisting in agenda development, chairing the meeting and helping participants to use the technology.

The combination of these three groupware components can have significant effects on three major causes of BPR failure: prolonged analysis, quality and creativity of the redesign ideas and insufficient involvement of top management, middle management and workers $[6,9,23,25]$. First, use of groupware can significantly reduce the time required to perform the analysis phase of BPR projects $[10,14]$. Second, groupware can significantly improve the quantity and quality of idea generation, particularly for larger groups $[12,17,47]$. It can also facilitate the production of radical ideas [39]. Finally, groupware can enable the use of larger groups so participants at all levels can be included $[11,35]$.

\subsection{Summary}

In its classic form, BPR had at least three key "rules": (1) a goal of radical, not incremental, improvement, (2) an emphasis on clean-slate changes and (3) a focus on small teams of top managers. Prior research has shown the goal of radical change to be risky, the emphasis on clean-slate analysis to be appropriate and the top management focus to be risky. Groupware has the potential to upset these rules by enhancing creativity for both incremental and radical change, by reducing the cost of analysis and by more easily enabling larger teams of senior and middle managers to participate.

\section{Method}

\subsection{Research design}

Given the process focus of our research, we chose to study several large-scale, groupware-based BPR projects from inception to implementation. We iden- 
tified four organizations interested in conducting groupware-based BPR that agreed to participate in our research if the researchers provided the groupware expertise. This study therefore uses action research [50], where the researchers are both participants and observers (Ref. [51], pp. 92-94). This method enables researchers to study unique situations but creates the potential for bias, because the researchers can become advocates for the groups or phenomena under study [50,51].

\subsection{A groupware-based BPR approach}

The groupware-based BPR approach used in this project follows that of the U.S. Department of Defense (DoD) [15] developed under Strassmann $[41,42]$. It is similar to the approaches used by other organizations (cf. Refs. [16,29,30,31]). The process had five steps: (1) The team builds a model of the current (or "as-is") processes. (2) It analyzes this model to brainstorm a set of improvement ideas. (3) It builds a model of the new ("to-be") processes. (4) It designs in detail the business systems and information systems to support them. (5) It implements them. Groupware is primarily involved in the first three steps, so our focus is on these. The approach is described in more detail in the Appendix A. Clearly, this approach allows for deviation from the ideal BPR approach. It includes both radical and incremental change, it avoids clean-slate analysis in favor of more detailed analysis of current processes and it encourages the involvement of middle managers.

\subsection{Groupware tools}

The groupware software used in the U.S. Army project, the Allied Army project and the IT company project was GroupSystems [46], while VisionQuest [34] was used in the food service company project. These packages provide a set of general-purpose tools to support idea generation, idea organization and voting. Our initial trials found these packages to be helpful but to lack the structure and graphics required for business process modeling. We developed our own groupware-modeling tool, which we used for the U.S. Army, the food service company and the IT company projects. We used a beta version of GroupSystems' Enterprise Modeler for the Allied Army project.

\subsection{Data collection}

We used two primary sources of data. The first was our direct involvement with the projects for the first three stages in the process (as-is modeling, analysis and to-be modeling). During these stages, the authors were members of the project management teams and participated in and/or observed all meetings. The second primary source of data was interviews (both focused and open-ended) with members of BPR teams. These interviews were conducted while we were actively involved in the projects as participantobservers and continued after our direct involvement ended until well after implementation or termination of the projects.

\section{Analysis}

The following sections report the processes and outcomes for BPR projects at four different organizations: the U.S. Army, the Allied Army, a food service company and an IT company. As Halachmi [21] notes, two major differences between private sector and public sector BPR are that the public sector is less accepting of radical change and it has less control over its processes (e.g., more likely to be constrained by other parts of the organization and by laws and regulations). Nonetheless, the goals for all four projects were both radical and incremental change.

\subsection{U.S. Army installation management}

This case presents an example of how the U.S. Army reengineered nine interrelated processes that spanned as many as 17 different functional departments. The primary problem facing the Army was the enormous cost of managing the Army's installations (US\$5 billion annually) due to the many diverse processes and computer systems developed by individual installations. The objective of the BPR project was to develop a standard set of business processes and technology that could support both the standard installation activities required by regulations yet be flexible enough to support any local requirements instituted by the installation commander. A colonel served as the project leader with a three-star general as 
the project's executive sponsor. It lasted 6 years from inception to implementation and cost about US\$250 million (including the software and hardware for implementation).

\subsubsection{The process}

The project began with a 9-week nongroupware meeting of seven midlevel managers who were subject matter experts in the processes to be reengineered. The team identified nine key processes and developed the fundamental concept by which the nine separate processes would interact in the new installation management processes. This concept was then presented to, approved by and funded by the Army's senior leadership.

Only then did the project proceed. The project management team developed an approach to reengineer each of the nine major processes in sequence, designed to ensure that the resulting processes would still fit into the overall integrated concept. Because many of the Army's installations had quite different existing processes, the team decided to forgo building as-is models of the current processes and instead focus solely on redesign. The project team established a standard 1-week groupware-based meeting agenda for each of the nine processes to be reengineered. Due to time constraints, the sole redesign activity was a simple incremental analysis of current problems (rather than attempting to employ any radical redesign techniques), followed by building the to-be model based on its results. In general, 18-22 midlevel managers (primarily lieutenant colonels and majors) drawn from all major Army commands participated in each redesign meeting. Representatives from the BPR project management team, the Office of the Chief of Staff, the Army Research Laboratory and the senior command responsible for each of the processes (i.e., its "owner") were also present. The groupware-supported redesign meetings began in early 1990 but were interrupted by the Gulf War, so the BPR activities were not finished until mid-1991.

Once the to-be models were completed, they were presented to senior executives for approval (early 1992). They were then circulated to all major commands for approval (late 1992). Once accepted (most with minor changes), a prototype information system was developed and pilot tested at 12 installations. In most cases, only a few additional functionalities were identified, but in some cases, several significant new ones were added. Installation of seven of the nine new installation processes and information systems began in mid-1994 and it was completed by late 1995. The remaining two reengineered processes were not implemented.

\subsubsection{Analysis}

Our analysis focuses on the groupware use followed by possible reasons for the success or failure of the project. Groupware could be used to speed as-is modeling of the current processes, increase the number of participants or facilitate the generation of more ideas and/or more radical ideas. In this project, no asis modeling was done. Standard agendas were used to conduct meetings for representatives for all impacted commands, thus facilitating participation by a greater number of impacted parties (including middle managers) during the design phase of the project. Groupware use, through the standard agendas, focused on idea generation using techniques aimed at generating increment ideas. The cost and time savings from using groupware was also important. The project manager estimated that groupware use cut the time from project initiation to implementation by $40 \%$ (2$1 / 2$ years). This was accomplished by shortening the design time and by enabling representatives from all commands to be actively involved in designing the new process to mitigate objections and rework during the Army-wide evaluation. He also estimated that groupware use cut the design cost from US\$1.2 million to US $\$ 400,000$.

The U.S. Army considered the project a success, even though two of the nine new processes were not implemented. Based on a detailed functional economic analysis conducted by the Department of the Army, one reengineered process alone saved an estimated US $\$ 400$ million in terms of direct out-ofpocket costs for computer upgrades with an ongoing annual savings of US\$100 million.

What factors in the process contributed to its success? Contrary to the classic BPR process, the project used a combination of radical and incremental change - the way they were combined is of interest. The initial concept was radical, but the project management team developed the idea and secured the funding early in the process. Middle managers were brought in after this and they, using groupware, 
generated the incremental ideas that would be used to implement the radical idea.

Contrary to the classic BPR process, the project was not conducted by a small team of senior managers. The fundamental concept for the new process was developed by small team of middle managers and then presented to senior management for approval before the project continued. Once this had been approved, middle managers and even clerks (e.g., corporals) actively participated in the analysis and design of the processes. Some of the changes from these analyses were rather radical, but all radical changes had been proposed as possibilities in the briefings to the Army's senior management as part of the original concept at the start of the project.

We believe that this project was a success because the Army's senior managers approved the radical changes before much of the detailed work began, remained involved through participation in the groupware sessions and maintained their commitment for the life of the project through numerous budget cuts. Even though the project manager retired halfway through the project and a new three-star general took over as executive sponsor, the project had sufficient momentum to continue.

\subsection{Allied Army}

This case examines how the Allied Army attempted to reengineer the processes and organizational structure of the headquarters responsible for command of all land forces. There were two major problems facing the headquarters. First, many processes were interfunctional, requiring the involvement of several areas within the headquarters, so there was considerable inefficiency and frustration to accomplish even the simplest of tasks. Second, each of the areas had the ability to issue orders to units under the headquarters' command, so it was not uncommon for units to receive conflicting orders unknowingly issued by the different areas, which was not only embarrassing but also potentially costly.

\subsubsection{The process}

The Allied Army BPR project was led by a major (promoted to lieutenant colonel during the project) and began under the sponsorship of the headquarters chief-of-staff (a one-star general). This project lasted
12 months from inception until it was terminated at cost of about US $\$ 100,000$.

The project began with a very quick development of an as-is process model for the headquarters. Nine small teams of middle managers (five to eight members) spent 1 day building each of their parts of the overall model. There was considerable resistance among the middle managers to becoming involved in the BPR process, and when the sponsor was transferred soon after the project began, it languished for 6 months. Then, the commanding general of the headquarters (a two-star general) became interested in the project as the fundamental problems within the command became clear after several highly noticeable incidents.

The project was restarted with a concentrated push over a 2-month period in which the management team worked almost full time on the project. The general made it clear to the management team and all members of the headquarters staff that he wanted radical change and that the improvement plan should come from the middle managers in the headquarters who were most familiar with the processes and structure. The management team created 10 teams of middle managers (lieutenant colonels, majors and captains), this time organized around 10 cross-functional processes (e.g., ensure preparedness, manage resources and conduct operations) rather than on functional lines as for the as-is model. The groupware was used to support both incremental and radical analyses.

There was still some initial reluctance among the middle managers, but this gradually changed into strong support as the scope of the changes developed by the teams began to emerge. The final proposed changes eliminated three functions and reorganized the headquarters structure around five major processes. Once the scope of the change became clear to the commanding general, he issued orders that prevented any radical change. The project died.

\subsubsection{Analysis}

This project used the groupware to produce as-is models to generate more ideas as well as more radical ideas. It was also used to involve a greater number of people in the analyses. Nonetheless, this project clearly was a failure. The project followed the rules in that the initial goal of the project was radical change. However, it broke the rules in that clean-slate 
analysis was not used and the project was conducted by multiple teams of middle managers, not a small team of senior executives.

The use of some process modeling, rather than a clean-slate analysis, helped the middle managers realize how convoluted the existing processes were. Many radical ideas were suggested based directly on the analyses of the as-is process models. We believe that the use of a modest analysis of the as-is processes helped the project and did not contribute to failure.

The primary cause of failure was the purported desire for radical change, coupled with a lack of top management involvement in the idea generation. The middle managers conducted the project and did all of the analysis and planning; no senior executives were involved. Although the middle managers initially were not supportive of the project, they became very interested when they realized how the changes could positively affect their jobs. They openly lobbied for radical change, both to their functional managers and to the senior headquarters staff. The middle managers felt they were empowered to make radical change - as senior management had directed-but in fact they were not; the commanding general reserved the final decision-making for himself. The project team failed to involve the general. Thus, the final proposals did not match his views. Had he played a more direct role in the project, he might have steered the project closer to his views or, alternately, might have been coopted by the middle managers and become more convinced of the value of the changes developed. In this case, the use of middle managers, not a top management team, doomed the project to failure.

\subsection{Food service company}

The food service company is a multibillion-dollar food service company that operates about four restaurant groups with a total of about 2000 fast food restaurants in the US. The company began four nongroupware BPR projects with the assistance of a consulting firm renowned for its reengineering expertise. After spending several million dollars, three projects ended in failure; only one was implemented. The key problems identified by the company's reengineering "czar" that led to failures were "wasted" time in meetings due to group dynamics problems, the use of clean-slate analysis and the lack of a tactical methodology that led to a lot of "floundering" for direction and high cost.

After these projects, the company decided to try groupware-supported BPR, because it might address some of the problems with the manual method. The goal of the groupware project was to reengineer three functions within the administration group (communications-i.e., mailroom, fleet operations and travel administration). The project was led by the reengineering "czar" under the sponsorship of the vice president for administration. The project lasted 18 months from initiation to implementation and cost less than US\$100,000.

\subsubsection{The process}

The project began with detailed modeling of the asis processes. Three project teams of three to five middle managers were formed (the vice president of administration participated occasionally, until he resigned midway through the project). The three teams then performed the analysis using radical BPR techniques. The teams also investigated the processes in more detail by observing existing processes and interviewing managers throughout the headquarters. These analyses resulted in a large set of potential improvement opportunities, including incremental and radical changes.

The next step was to seek wider participation from executive management and the four restaurant groups. The company's only groupware room was small (eight workstations) and not ideal for the large groups usually used in BPR, so to accommodate the wide participation needed, the team designed a standard $2-3$ hour agenda for meetings with representatives from key areas. The agenda presented the as-is models and some initial ideas for the reengineered processes and asked the participants to generate both incremental and radical ideas for improvements. Nine groups participated: marketing, IT, finance, key administrative assistants, selected restaurant general managers and the executive teams (COO and VPs) of three restaurant groups.

The ideas identified by these groups were integrated with those of the reengineering teams and developed into a set of proposals for change that were implemented within 1 year. The original idea for the mailroom process, prior to the BPR project, was to either outsource it or use optical imaging to reduce paper flow. These two radical ideas figured prominently in 
the analysis phase of the project, each with an estimated 50\% savings. While these were being debated, the mailroom manager implemented five incremental improvement ideas that came from the reengineering process: better workflow procedures, better training, reduced supervision, cutting the number of mail deliveries each day and requiring all vendors to fax invoices to a computer that stored them digitally. These five incremental improvements cut costs by $50 \%$ within 2 months, making radical change unnecessary.

After a thorough analysis of its as-is model, the fleet operations function realized it was so closely tied to its primary vendor that it recommended outsourcing, an idea it got from the outsourcing discussed for the mailroom function. The vendor used the as-is and to-be models extensively in designing the new end-toend fleet operations process. Costs were cut by $50 \%$.

The travel function cut costs by $30 \%$ due to some incremental changes and a change to telecommuting. While regarded as successful, the impacts for this function were less than hoped for.

\subsubsection{Analysis}

The project used the groupware tool to create an as-is model, generate more ideas and more radical ideas and involve more people in the project. Compared to the prior nongroupware BPR project, the reengineering czar estimated that the use of groupware cut the working time by $80 \%$ and significantly reduced costs. Total costs for the groupware project (including the startup costs of buying computers, software and training) were less than US\$100,000 compared to several million for the previously mentioned manual projects.

The project was a success, resulting in annual savings of about US\$500,000. The project broke all three rules. First, a combination of radical and incremental change techniques was used. The mailroom project began with the expectation of radical change, but this was rendered meaningless by incremental changes that brought the same impact. In contrast, fleet operations outsourced itself (the idea came from the fleet manager and her staff), while travel implemented only minor changes plus the preexisting idea of telecommuting.

Second, the use of detailed process modeling and analysis, rather than a clean-slate approach, was key to the success of both mailroom and fleet projects.
The detailed process modeling identified several of the incremental changes that led to the $50 \%$ improvement for the mailroom and helped the fleet manager recognize the degree of interconnectedness between food service company and its primary vendor. We, and the reengineering czar, believe that neither project would have succeeded without the detailed process modeling and analysis.

Finally, there was again a somewhat unusual combination of senior executives and middle managers involved. The middle managers formed the core reengineering team and did most of the analysis and planning. Senior executives were brought in towards the end to gather their opinions and to involve them (or coop them) in the change process.

\subsection{IT company}

This project focused on a major accounting process within a multibillion dollar multinational firm in the information technology sector. The senior management of the firm had undertaken a number of highly publicized BPR efforts with the assistance of the same consulting firm renowned for its reengineering expertise as food service company. While some of these were successful, most were widely regarded as failures within the firm itself. The senior corporate accounting executive felt that there was the possibility that the use of groupware might address some of the problems the firm had encountered with manual BPR.

The corporate accounting process was used by all of the firm's US branches (approximately 1000) for billing, inventory, sales commissions and so forth. The corporate accounting group had previously launched a major initiative to improve quality, and while the results were successful, the error rate was still more than 100 times the target rate. The group decided that to achieve the target error rate it had to radically redesign its business processes. The project lasted 5 months, from initiation until it was terminated, and cost about US $\$ 40,000$. The project was led by a middle manager under the sponsorship of the senior executive.

\subsubsection{The process}

The project team was composed of 15 middle managers from the accounting group and other organizations with which the group interacted. The team built a detailed as-is process model and then used a mix of 
incremental and radical analysis techniques. This resulted in more than 50 single-spaced pages of ideas, which were organized and filtered into a set of proposals.

This filtering step proved crucial in the overall project. Many ideas considered radical by the research team were eliminated, because the middle managers on the reengineering team saw the radical ideas as "not practical" or "would never be accepted" by senior executives (e.g., eliminating legal contracts between the firm's own departments and letting the "customer" department play a larger role in prioritizing and scheduling). Senior executives felt the resulting proposals were not radical enough and did not receive them favorably. The team returned to the analysis phase, but the corporate accounting group was reorganized and the top three managers reassigned to different units. The project died.

\subsubsection{Analysis}

This project used groupware to create the as-is model, generate more ideas and more radical ideas and involve more midlevel managers in the process. The project was a failure. The project followed the rules in that the goal of the project was radical change (given the insufficiency of past incremental efforts). However, the project broke the clean-slate and top management rules. The use of detailed process modeling and analysis, rather than a clean-slate approach, may have been a factor in the project team's drive to incremental solutions, but we do not believe it was a major factor. Many radical ideas were suggested but were filtered out at the last stage. The middle managers clearly did not believe that the radical BPR strategy as espoused by top management was legitimate; they did not believe that radical change was desired.

Thus, we believe that the lack of senior executive participation was the key factor in the failure. Without senior executives involved, the middle managers felt unable to recommend radical change. They viewed the ideas they initially developed as too radical and thus presented ideas too incremental in their scope.

\section{Discussion}

The previously described groupware support for the BPR process in practice is summarized in Table 1.
In this section, we look across the four case studies to draw conclusions. Our observations are categorized by the classic rules presented earlier, and within each, we describe the factors present in the successful cases and absent in the unsuccessful ones that we believe contributed to the outcome. Table 2 summarizes the analyses.

\subsection{Radical change}

Classic BPR proponents have argued that only radical analysis should be done, because incremental thinking can lead to incremental changes, which only make the process worse [23-25]. These beliefs are founded on the idea that incremental change cannot accumulate in such a way as to bring about the radical transformation that classic BPR was meant to produce. More recently, researchers have suggested that BPR design must be radical, but the implementation may be more successful as a series of incremental steps [27]. Even Hammer now admits that "radicalness" is not as important as a solid process-based analysis [20].

In all four cases, both radical and incremental groupware techniques were used in varying ways. In general, participants felt more comfortable using incremental techniques over radical techniques, perhaps because they were simpler or appeared more focused and productive. The most commonly used technique was simply an analysis of current problems, perhaps because it seemed the most "rational" to managers or perhaps because it is easier to sell solutions to problems than innovative new ideas.

In the successful cases, the U.S. Army and the food service company fleet projects, major changes came from one radical idea, supported by a host of incremental improvements. The U.S. Army project produced the radical idea during the planning meetings and gained senior-level approval before any analysis was done. Further, the analysis that included middle managers was focused on identifying an incremental process that could be used to arrive at the radical end result. In the food service company case, the mailroom manager opted to implement a set of five $10 \%$ improvements that provided the same benefit as one $50 \%$ radical change and was easier to implement. This was an example of Davenport's [8] "tidying up the room while the bulldozer waits outside" in which 
Table 1

BPR process used in each site (bold indicates groupware in use)

\begin{tabular}{|c|c|c|c|c|}
\hline Site & Planning & Analysis & Approval & Implementation \\
\hline U.S. Army & $\begin{array}{l}\text { - 9-week preplanning for } \\
\text { project management team } \\
\text { - Processes to be } \\
\text { redesigned are identified } \\
\text { - Standard groupware } \\
\text { agenda made } \\
\text { - Basis of radical } \\
\text { redesign formulated }\end{array}$ & $\begin{array}{l}\text { - 1-week groupware meeting } \\
\text { held for each process } \\
\text { - Groupware session used } \\
\text { incremental techniques } \\
\text { - Middle managers involved }\end{array}$ & $\begin{array}{l}\text { - Senior management } \\
\text { approval sought } \\
\text { before analysis } \\
\text { - Process owner } \\
\text { approval sought } \\
\text { prior to implementation }\end{array}$ & $\begin{array}{l}\text { - Prototype, } \\
\text { feedback, } \\
\text { incremental } \\
\text { improvements }\end{array}$ \\
\hline Allied Army & $\begin{array}{l}\text { - As-is modeling } \\
\text { performed in } \\
\text { prior BPR initiative } \\
\text { - New leadership asks for } \\
\text { radical change led by } \\
\text { middle managers }\end{array}$ & $\begin{array}{l}\text { - Groupware session used } \\
\text { both incremental and } \\
\text { radical techniques } \\
\text { - } 10 \text { teams organized around } \\
\text { business processes included }\end{array}$ & $\begin{array}{l}\text { - Ideas presented to } \\
\text { management }\end{array}$ & $\begin{array}{l}\text { - Killed, perceived as } \\
\text { "too radical" } \\
\text { - In fact, not the radical } \\
\text { idea top management } \\
\text { had in mind }\end{array}$ \\
\hline Food service & $\begin{array}{l}\text { - Identified three processes } \\
\text { for reengineering } \\
\text { - Formed three projects teams of } \\
\text { three to five middle managers } \\
\text { - Detailed as-is modeling under } \\
\text { direction of project } \\
\text { management team }\end{array}$ & $\begin{array}{l}\text { - Groupware session for } \\
\text { project teams used } \\
\text { radical techniques } \\
\text { - Teams were not allowed to } \\
\text { redesign their own processes } \\
\text { - } 2-3 \text { hour standard agenda } \\
\text { created for Groupware } \\
\text { sessions for process workers }\end{array}$ & $\begin{array}{l}\text { - Extra groupware } \\
\text { session conducted for } \\
\text { business process workers; } \\
\text { used radical and } \\
\text { incremental techniques }\end{array}$ & $\begin{array}{l}\text { - Set of proposals } \\
\text { provided to business } \\
\text { process owners } \\
\text { - Owners chose which } \\
\text { to implement }\end{array}$ \\
\hline IT company & $\begin{array}{l}\text { - Formed project team of } \\
15 \text { middle managers } \\
\text { - Built detailed as-is model }\end{array}$ & $\begin{array}{l}\text { - Groupware session used } \\
\text { both radical and } \\
\text { incremental techniques } \\
\text { - List of generated } \\
\text { ideas is filtered }\end{array}$ & $\begin{array}{l}\text { - Filtered ideas presented } \\
\text { to management }\end{array}$ & $\begin{array}{l}\text { - Rejected, } \\
\text { not radical enough } \\
\text { - Radical ideas } \\
\text { had been filtered }\end{array}$ \\
\hline
\end{tabular}

incremental changes are implemented immediately while radical changes await further analysis, but the results of implementing the incremental changes made the bulldozer unnecessary.

The projects that failed did so because the level of change on which the team focused (i.e., radical or incremental) did not coincide with managerial inten- tions. The groupware tools were capable of leading the team to more or less radical ideas, but the meeting facilitator had to be aware of the desired outcome. This could be accomplished in a number of ways. The U.S. Army project accomplished it by deciding upon the radical outcome and gaining approval for it prior to the groupware sessions. The food service company

Table 2

Case analyses

\begin{tabular}{|c|c|c|c|c|}
\hline & U.S. Army & Allied Army & Food service company & IT company \\
\hline $\begin{array}{l}\text { Success or failure } \\
\text { Rules: }\end{array}$ & Success & Failure & Success & Failure \\
\hline Radical change & Radical and incremental & Radical and incremental & Radical and incremental & Radical and incremental \\
\hline Clean-slate analysis & Clean slate & Quick as-is model & Full as-is model & Full as-is model \\
\hline Top management teams & $\begin{array}{l}\text { Middle management teams, } \\
\text { with periodic top } \\
\text { management consultation }\end{array}$ & Middle management teams & $\begin{array}{l}\text { Middle management teams, } \\
\text { with periodic top } \\
\text { management consultation }\end{array}$ & Middle management teams \\
\hline
\end{tabular}


conducted special groupware sessions for corporate management to gain their input before any recommendations were made.

\subsection{Clean-slate approach}

One of the debates within the BPR community is over the relative cost and benefit of building an as-is model of current processes and conducting detailed analyses. Proponents of classic BPR [22,25] advocate a clean-slate approach with no as-is modeling or detailed analysis. In contrast, the project leaders in three of the four cases here felt that process modeling and detailed analyses were important, particularly for the communication and learning that occurred. The food service company reengineering czar in particular was adamant that modeling was crucial to its success.

For these four organizations, the clean slate versus detailed analysis decision was a matter of logistics rather than philosophy. The more people involved and more complex the process, the more costly and time-consuming as-is modeling becomes and the greater the chance of "analysis paralysis." The two projects that eliminated or significantly reduced as-is modeling did so for cost reasons, not the philosophical grounds of classic BPR [22,25]; both project leaders would have preferred to do more modeling but could not justify the time or costs. We believe that any BPR project that involves people with detailed knowledge of current processes will almost certainly produce discussion of the as-is process, whether or not it is in the formal agenda. Without a formal step to address the as-is issues, the project will flounder because participants will keep dragging the BPR team back to these issues. Once they are discussed and recorded, the group can move on. To some extent, the use of groupware makes analysis paralysis less of an issue. Groupware can significantly improve modeling productivity [14], making as-is modeling cheaper and faster. The reduced time and increased understanding makes it practical for the as-is model to serve as a foundation of BPR instead of the source of analysis paralysis. Clear evidence of this phenomenon was shown in the food service company case. Three of their four nongroupware projects failed and the lack of as-is modeling was cited as a major contributor to this failure. Using groupware, three projects were undertaken successfully and they believed the as-is modeling contributed to their success.

\subsection{Top management teams}

In both successful cases and both failures, middle managers led the reengineering effort. They formed the core of the reengineering teams and performed most or virtually all of the analyses. One key difference between the successes and the failures was that in the two successful cases, the reengineering team met with senior managers early in the reengineering project and presented them with the initial results and general concepts for change. The senior managers were then able to understand, respond to and redirect the projects in subtle ways before too much work had been done. In contrast, in the two failures, senior executives were involved in the projects only near their end after much work had been done and thus did not have the chance to redirect the projects early on.

There is a crucial difference between top management involvement as in these cases and top management leadership as argued by Hammer and Champy [25]. Teams of middle managers, not teams of senior managers, conducted all four projects in this study. The middle managers formed the core of the BPR initiative, and in the two successful cases, senior executives provided guidance and approval to their plans at several key points in the project.

Why is active senior management involvement needed? Hammer and Champy [25] argue that middle managers lack the vision and power to identify and make the changes. We disagree - at least with the issue of vision. In the two successful cases, middle managers generated the ideas from which the implementation plans were created. In the two failures, middle managers identified many radical changes (although at the IT company they were eliminated from the final proposal for being too radical). Most of the problems came from the senior executives (or middle managers' perceptions of senior executives) or from a misalignment of the middle managers proposals with the senior executives' visions.

We believe senior management involvement is important for three reasons. First, it serves as a signal 
that the project is important, something that would have helped reduce the initial reluctance to participate in the Allied Army case. Second, it helps ensure that the project results are aligned with the rest of the organization's initiatives known to senior management. Third, and we believe most importantly, involvement helps senior management understand the real issues. At least in our four cases, senior management was often isolated from the day-to-day operational issues that are critical to understanding the business.

The successful cases also show that the involvement of middle managers is important to success. Without the practical up-to-date understanding of the business offered by middle managers, these projects would not have succeeded. In these projects, senior management became the catalyst: setting vision, opening boundaries and motivating middle management to enact change or else have someone else thrust change upon them. Middle management became the BPR core, identifying opportunities and designing new processes. Middle managers owned the change, making implementation simpler than if they had not been involved.

It is also important to ensure horizontal participation in the projects (i.e., actively involving "customers" and "suppliers" of the process, whether external or internal, because they will be affected by the changes). A more radical approach is the active involvement of noncompeting companies in the project. The benefits can be substantial, because outsiders are less bound to the status quo and can draw insights from different experiences. The Allied Army included representatives from several other armies in its project who offered insight into how those armies performed the same functions. Likewise, several key insights for the three food service company processes were gained from individuals working on the other processes.

\section{Implications for research and practice}

With the use of groupware, these companies were able to efficiently create as-is models, generate both incremental and radical ideas and gain broader participation in the reengineering effort. We believe this study has important implications for research and practice. From a practical perspective, it offers insights into a BPR process that can succeed despite its deviation from the ideal process. Table 3 illustrates a "best practice" groupware-supported BPR process derived from the experiences in these cases.

As our case studies illustrated, use of groupware to support detailed as-is modeling during the planning phases of BPR is a best practice. Clean-slate analysis was not a necessary condition for success in our cases. In fact, as-is process modeling played an important role in these projects. In our opinion and the opinions of the project leaders in these organizations, detailed analysis is likely to be more successful than cleanslate analysis.

During the analysis phase, groupware with preset agendas was used in our successful cases to facilitate participation by a wide range of people. Middle management teams played an important role in these projects. We disagree with Hammer that BPR must be led by senior managers. In our cases, the key ideas for change came from middle managers, not senior managers. Further, groupware can be used to influence the types of ideas generated [18]. In our successful cases, the BPR team chose groupware tools that supported the creation of radical redesign ideas but incremental implementation ideas. Management approval was sought at key intervals and implementation plans were provided.

In general, the primary cause of failure in our public and private organizations was the lack of senior executive involvement. The groupware tool could provide good support for bilateral communication and it could facilitate greater involvement. It could not provide a substitute for good top-down communication of top management support or the top-down communication of BPR strategy. The organizations that failed to achieve their BPR goals did not have good top-down communication of support or strategy.

The sector in which the organization operated also appeared to play a role. The public organization that succeeded differed from the private organization in two ways: the frequency and timing of management approval and the nature of the implementation plan. Public administration researchers have argued for decades that public organizations are different in significant ways from private ones [36] and it has been empirically substantiated that public organiza- 
Table 3

Groupware-supported BPR "best practice" guidelines

\begin{tabular}{|c|c|c|c|c|}
\hline & Planning & Analysis & Approval & Implementation \\
\hline $\begin{array}{l}\text { Private } \\
\text { organizations }\end{array}$ & $\begin{array}{l}\text { - Project management team } \\
\text { identifies process(es) } \\
\text { to be reengineered } \\
\text { - Groupware-supported, } \\
\text { detailed as-is modeling }\end{array}$ & $\begin{array}{l}\text { - Groupware sessions } \\
\text { including as many middle } \\
\text { managers and other } \\
\text { affected parties as possible } \\
\text { - Preset agenda } \\
\text { - Use of radical techniques } \\
\text { for redesign ideas } \\
\text { - Use of incremental } \\
\text { techniques for } \\
\text { implementation ideas }\end{array}$ & $\begin{array}{l}\text { - Redesign ideas must be } \\
\text { approved by } \\
\text { senior management } \\
\text { - Participation in } \\
\text { analysis preferred to } \\
\text { solicitation of } \\
\text { approval afterward }\end{array}$ & $\begin{array}{l}\text { - Middle managers } \\
\text { given choice of } \\
\text { implementation } \\
\text { options_preferably drawn } \\
\text { from a list they helped create }\end{array}$ \\
\hline $\begin{array}{l}\text { Public } \\
\text { organizations }\end{array}$ & $\begin{array}{l}\text { - Project management team } \\
\text { identifies process(es) } \\
\text { to be reengineered } \\
\text { - Groupware-supported, } \\
\text { detailed as-is modeling }\end{array}$ & $\begin{array}{l}\text { - Groupware sessions } \\
\text { including as many } \\
\text { middle managers and } \\
\text { other affected parties } \\
\text { as possible } \\
\text { - Preset agenda } \\
\text { - Use of radical techniques } \\
\text { for redesign ideas } \\
\text { - Senior management approval } \\
\text { - Use of incremental } \\
\text { techniques for } \\
\text { implementation ideas }\end{array}$ & $\begin{array}{l}\text { - Approval needed } \\
\text { more frequently } \\
\text { - Participation in } \\
\text { analysis less necessary, } \\
\text { anonymity feature of } \\
\text { groupware obscures } \\
\text { managerial message }\end{array}$ & - Formal implementation plan \\
\hline
\end{tabular}

tions are more formal and exhibit less autonomy and control over decision-making [37].

BPR researchers have found that in public organizations the multiple departments and levels of authority require not only top management support for the reengineering effort in general but also approval of the redesigned processes [44]. Our successful public organization sought top management approval of the BPR process at key intervals. The processes targeted for redesign were approved, then the redesign ideas were approved and finally the implementation plans were approved. In essence, the public organization had to more formally seek on-going support than the private sector organizations did. Further, the implementation plan was more formalized than the one used in our successful private organization as suggested by previous research [44].

Finally, in all four cases, either the project manager or the project sponsor left the organization during the BPR project. We do not know if this is representative of BPR projects in other organizations, but if it is, the message is clear: BPR projects must be planned so that they do not rely on the skills and abilities of one person. Succession planning is important.

\section{Conclusions}

BPR efforts can be improved - and impairedthrough the use of groupware. Our successful cases provide insight into the "best practice" for doing this. Interpreting the outcomes within the context of sector enhances the results.

While we believe our conclusions to be accurate, this study suffers from the same limitations as other field-based research of this kind: a qualitative study of a small sample studied in depth. Clearly, more research on groupware-supported BPR is needed.

One important question for future research is the failure rate for groupware-supported BPR versus traditional BPR. Two out of the four cases studied were failures, suggesting a 50\% failure rate (owing at least in part to the lack of senior management involvement). If we look more closely at the food service company case where senior management was involved, we see that three out of three groupwaresupported BPR projects succeeded, while three of out four traditional projects failed (even though senior management was involved). Clearly, we cannot generalize these findings beyond this one case, but is suggestive of a pattern that calls for more research. 
Another issue for future research is that of the analysis approach used, whether clean slate or detailed analysis. We believe that the detailed analysis approach of process modeling and both radical and incremental analysis is most successful. It may be that the detailed analysis approach is only successful when combined with groupware. Groupware enables this process to be done quickly and cheaply and to involve wide cross-sections of the organization. Without groupware, the detailed analysis approach may significantly increase the risk of analysis paralysis.

This study also raises the question of the long-term effects of empowerment and involvement of middle management on radical change. While classic BPR proponents argue that middle management hampers change [25], we found the opposite. In the food service company and Allied Army cases, middle management proposed and actively campaigned for changes that would both radically change their jobs and eliminate them (in both cases, middle managers knew that eliminating their positions would not cause them to lose their jobs). Middle managers were the engine of radical change, not the brakes. If middle managers are empowered in BPR projects, will BPR be more successful?

\section{Acknowledgements}

We would like to thank Warren Barker, Richard Brown, Wesley Brown, Colonel Wayne Byrd (retired), Dr. Robert Daniels, Dr. Glenda Hayes, David Howell, Dave Lange, Lawrence Massman, Dr. Jay Nunamaker, Dr. Ramesh Venkataraman and Lt. Colonel Philip Volk for assisting our research. We would also like to thank the hundreds of individuals who participated in this research and who offered helpful suggestions and insights. An earlier version of this paper won third place in the Society for Information Management Annual Paper Competition.

\section{Appendix A. A groupware-based BPR approach}

\section{A.1. As-is process modeling}

The process modeling technique used was IDEF0, a technique based on the SADT technique [38] originally developed in the 1970s, which has because been refined for use in the DoD's BPR efforts $[1,32]$. The fundamental building block of an IDEF0 model is an activity. Each activity in the overall business process has (1) a number, (2) a name, (3) a short definition (typically two to four sentences in length) and (4) a set of Inputs, Controls, Outputs and Mechanisms (ICOMs) that define how the activity interacts with other activities and entities outside the model. This is often presented graphically with the text definition as a supplement. Inputs and Outputs are self-explanatory - the information and things that the activity receives and produces. Controls are those items that guide how the activity is performed (e.g., policies and rules). Mechanisms are resources used to perform the activity (e.g., people, IT and machines). In general, every activity has at least one input, one control and one output, with an ideal maximum of six inputs, six outputs, six controls and six mechanisms per activity.

IDEF0 is a hierarchical modeling technique in which activities are decomposed into subactivities (also called "children"), which in turn are decomposed into sub-subactivities (also called "grandchildren") and so on. Activity numbers indicate the level of decomposition. Activity A11 is the child of activity A1 and so on. ICOMs also can be decomposed, so that ICOMs at parent activities are gradually decomposed into more detailed ICOMs at the children activities (e.g., Reports at A1 becomes split into Personnel Reports, and Financial Reports at A11).

\section{A.2. Analysis}

The fundamental objective of the analysis step is to rethink how the business process is performed. The BPR team looks at the process model from many different perspectives. Von Oech [48] identifies two basic approaches to idea generation. The first, "soft thinking," is highly creative, nonrational, open-ended and ambiguous and tends to lead to radical ideas. The second, "hard thinking," is logical, rational, analytical and precise and tends to lead to incremental ideas. We normally begin with radical techniques followed by incremental techniques, because radical techniques are more open ended. Once the group has become closely focused on the process model, as occurs 
during the incremental techniques, it becomes more difficult to move them to more open-ended radical thinking.

Table 4 summarizes some of the redesign techniques used. Not all techniques are used in all projects. Ideally, each of these techniques will encourage the redesign group to see their processes in a new way. However, if a group has difficulty building momentum with one technique, switching to another technique may help them relax and get a fresh start.

Once the group has generated a set of ideas using a variety of different methods, which in groupware projects is often $50-75$ pages, the group selects a short list of the best ideas, which are then rated on impact, feasibility, cost, etc. These ideas are then turned into formal proposals.

\section{A.3. To-be process modeling}

The next step is to develop an IDEF0 to-be Process model that can be used for further analysis of job responsibilities and to identify the IT required to support the new processes. This is done is the same manner as the as-is model above.

\section{A.4. Detailed development}

Usually, the new processes require some IT support and new business policies. This IT support is rapidly prototyped using some advanced application development tools (e.g., Power Builder) and pilot tested in several areas before being fully implemented.

Table 4

Redesign techniques

Radical techniques

Open brainstorming: The group generates open-ended ideas following the traditional rules of brainstorming (no criticism, wild ideas are encouraged, focus on quantity not quality, piggyback on the ideas of others). Participants are encouraged to start with a clean slate and no rules.

Future thinking: The group pretends it is the future and that the BPR effort has been successful. They describe the conditions, either in concrete detail (e.g., what can you see, hear, feel and taste) or by analogy or metaphor.

Principles and parables: The group is presented with a set of BPR principles and a parable for each that illustrates how one organization successfully implemented the principle.

Industry analogies: The group first generates a list of industries with similar structures to their own and then attempts to apply the ideas and techniques from those industries into their own. For example, for the hotel industry, industries that also have time-dependent inventories that vanish if not used (e.g., rock concert).

Breaking assumptions: The group generates a list of one-sentence assumptions or rules that constrain how the process operates. These can be formal rules, but often it is the hidden assumptions (the ones so obvious that no one thinks about them). The group selects a set of $20-50$ assumptions to break and generates ideas on how breaking each assumption could improve the process.

What-if games: The group selects a set of 5-10 unrealistic events that could affect the process and generates ideas on what they would change if those events happened. We have found that the most productive events relate to scaling the workforce and time up and down by $90 \%$.
Incremental techniques

Problem analysis: The group first generates a list of problems and prioritizes it into a short list of 10-30 key problems. The group then generates ideas to solve these problems.

Cost analysis: The group examines the IDEF0 model and develops cost information for each activity in the model (i.e., activity based costing), either a full formal economic analysis or just a rough approximation.

Activity elimination: Every member of the group generates ideas on how every activity in the model can be successfully eliminated. This is a "force-fit" exercise; participants must eliminate all activities.

ICOM elimination: Every member of the group generates ideas on how every input-control-output-mechanism for selected activities can be successfully eliminated.

Duration analysis: The group examines the IDEF0 model and develops the time required to complete each activity in the model for a "typical" set of inputs. This is done at each level in the activity tree, because the time required to process an input through the lowest level activities may differ substantially from the end-to-end flow time as documented at higher levels in the tree.

Technology analysis: The group examines the "core" activities in the model and considers how new technologies can improve or eliminate them. Alternately, the group may start with a list of new technologies and try to force fit those onto the process. 


\section{A.5. Implementation}

Once pilot tested, the redesigned processes are implemented, often the hardest part of the entire process. Groupware designed to support the modeling and analysis steps adds little value here.

\section{References}

[1] AFWAL-TR-81-4023, IDEF0 Function Modeling, Armstrong Laboratory, Wright-Patterson Air Force Base, Ohio, 1981.

[2] A. Barua, C.H.S. Lee, A.B. Whinston, The calculus of reengineering, Information Systems Research 7 (4) (1996) 409418.

[3] J.R. Caron, S.L. Jarvenpaa, D.B. Stoddard, Business reengineering at CIGNA: experiences and lessons learned from the first five years, MIS Quarterly 18 (3) (1994) 233-250.

[4] D.K. Carr, H.J. Johansson, Best Practices in Reengineering: What Works and What Doesn't in the Reengineering Process, McGraw-Hill, New York, 1995.

[5] J. Champy, Re-engineering redux, Computerworld 37 (14) (2000) 14

[6] E.K. Clemons, Using scenario analysis to manage the strategic risks of reengineering, Sloan Management Review 36 (4) (1995) 61-71.

[7] E.K. Clemons, M.E. Thatcher, M.C. Row, Identifying the sources of reengineering failures: a study of the behavioral factors contributing to reengineering risks, Journal of Management Information Systems 12 (2) (1995) 9-26.

[8] T.H. Davenport, Review of reengineering the corporation, Sloan Management Review 35 (1) (1993) 103-104.

[9] T.H. Davenport, D.B. Stoddard, Reengineering: business change of mythic proportions, MIS Quarterly 18 (2) (1994) $121-127$.

[10] D.L. Dean, R.E. Orwig, J.D. Lee, D.R. Vogel, Technological support for group process modeling, Journal of Management Information Systems 11 (3) (1994-1995) 43-63.

[11] D.L. Dean, J.D. Lee, M.O. Pendergast, A.M. Hickey, J.F. Nunamaker, Enabling the effective involvement of multiple users: methods and tools for collaborative software engineering, Journal of Management Information Systems 14 (3) (1998) $179-222$.

[12] A.R. Dennis, J.S. Valacich, Computer brainstorms: more heads are better than one, Journal of Applied Psychology 78 (1993) $531-537$.

[13] A.R. Dennis, R.M. Daniels, G.S. Hayes, J.F. Nunamaker Jr., Methodology driven use of automated support in business process re-engineering, Journal of Management Information Systems 10 (3) (1994) 117-138.

[14] A.R. Dennis, G.S. Hayes, R.M. Daniels, Business process modeling with group support systems, Journal of Management Information Systems 15 (4) (1999) 115-142.

[15] DOD 8020.1-M, Functional Process Improvement, U.S. Department of Defense.
[16] T.R. Furey, A six-step guide to process reengineering, Planning Review, (1993) 20-23, March.

[17] R.B. Gallupe, A.R. Dennis, W.H. Cooper, J.S. Valacich, L. Bastianutti, J.F. Nunamaker Jr., Electronic brainstorming and group size, Academy of Management Journal 35 (2) (1992) 350-369.

[18] M.J. Garfield, N.J. Taylor, A.R. Dennis, J.W. Satzinger, Modifying paradigms: individual differences, creativity techniques and exposure to ideas in group idea generation, Information Systems Research 12 (3) (2001) 322-333.

[19] C.J.G. Gersick, Revolutionary change theories: a multilevel exploration of the punctuated equilibrium paradigm, Academy of Management Review 16 (1) (1991) 10-36.

[20] V. Grover, W. Kettinger, Process Think: Winning Perspectives for Business Change in the Information Age, Idea Group Pub., Hershey, PA, 2000.

[21] A. Halamichi, Re-engineering and public management: some issues and considerations, International Review of Administrative Sciences 61 (1995).

[22] M. Hammer, Reengineering work: don't automate, obliterate, Harvard Business Review (4) (1990) 104-112.

[23] M. Hammer, The art of change, Success 42 (3) (1995) 44a$44 \mathrm{~h}$.

[24] M. Hammer, Beating the risks of reengineering, Fortune 131 (9) (1995) 105-109.

[25] M. Hammer, J. Champy, Reengineering the Corporation, Harper, New York, 1993.

[26] M. Hammer, S.A. Stanton, The Reengineering Revolution, Harper Collins, New York, 1995.

[27] S.L. Jarvenpaa, D.B. Stoddard, Business process redesign: radical and evolutionary change, Journal of Business Research 41 (1) (1998) 15-27.

[28] P.G.W. Keen, Back to processes, Computerworld 34 (19) (2000) 50 .

[29] W.J. Kettinger, S. Guha, J.T.C. Teng, The process reengineering life cycle methodology: a case study, in: V. Grover, W.J. Kettinger (Eds.), Business Process Change: Reengineering Concepts, Methods and Technologies, Idea Group Pub., Harrisburg, PA, 1995.

[30] R.L. Manganelli, M.M. Klein, The Reengineering Handbook: A Step-by-Step Guide to Business Transformation, American Management Association, New York, 1994.

[31] M.G. Martinsons, Radical process innovation using information technology: the theory, the practice and the future of reengineering, International Journal of Information Management 15 (4).

[32] R.D. Mayer, IDEF0 Function Modeling, Knowledge Based Systems, College Station, TX, 1992.

[33] D.A. Nadler, R.B. Shaw, A.E. Walton, Discontinuous Change, Jossey-Bass, San Francisco, CA, 1995.

[34] M. Nagasundaram, G.R. Wagner, Goal centered dialogues: a process structuring model for group decision support systems, Proceedings of the 11th International Conference on Decision Support Systems, Manhattan Beach, CA, 1991.

[35] J.F. Nunamaker Jr., A.R. Dennis, J.S. Valacich, D.R. Vogel, J.F. George, Electronic meeting systems to support group work, Communications of the ACM 34 (7) (1991) 40-61. 
[36] H.G. Rainey, Understanding and Managing Public Organizations, 2nd ed., Jossey-Bass, San Francisco, CA, 1997.

[37] H.G. Rainey, S. Pandey, B. Bozeman, Research note: public versus private managers' perceptions of red tape, Public Administration Review 55 (6) (1995) 567-574.

[38] D.T. Ross, Structured analysis (SA): a language for communicating ideas, in: J.D. Couger, M.A. Colter, R.W. Knapp (Eds.), Advanced System Development/Feasibility Techniques, Wiley, New York, 1982.

[39] J.W. Satzinger, M.J. Garfield, M. Nagasundaram, The creative process: the effects of group memory on individual idea generation, Journal of Management Information Systems 15 (4) (1999) 143-160.

[40] D.B. Stoddard, S.L. Jarvenpaa, M. Littlejohn, The reality of business reengineering: Pacific Bell's Centrx provisioning process, California Management Review 38 (3) (1996) 57-76.

[41] P.A. Strassmann, The hocus-pocus of reengineering, Across the Board 31 (6) (1994) 35-38.

[42] P.A. Strassmann, The Politics of Information Management, Information Economics Press, New Canaan, CT, 1995.

[43] J.T.C. Teng, S.R. Jeong, V. Grover, Profiling successful reengineering projects, Communications of the ACM 41 (6) (1998) 96-102.

[44] J.Y.L. Thong, C.S. Yap, K.L. Seah, Business process reengineering in the public sector: the case of the Housing Development Board in Singapore, Journal of Management Information Systems 17 (1) (2000) 245-270.

[45] M. Tushman, W. Newman, E. Romanelli, Convergence and upheaval: managing evolutionary unsteady pace of organizational evolution, California Management Review 29 (1986) 29-44.

[46] J.S. Valacich, A.R. Dennis, J.F. Nunamaker, Electronic support for meetings: the GroupSystems concept, International Journal of Man Machine Studies 34 (1991) 261-282.

[47] J.S. Valacich, A.R. Dennis, T. Connolly, Group versus individual brainstorming: a new ending to an old story, Organizational Behavior and Human Decision Processes 57 (1994) $448-467$.

[48] R. Von Oech, A Whack on the Side of the Head, Warner Books, New York, 1983

[49] R.M. Walczuch, R.T. Watson, R.P. Bostrom, J. Day, Supporting reengineering using a group support system: a case study, International Journal of Information Management 15 (2) (1995) 97-104.

[50] W.F. Whyte, Participatory Action Research, Sage, Newbury Park, CA, 1991.

[51] R.K. Yin, Case Study Research: Design and Methods, Sage, Newbury Park, CA, 1989.

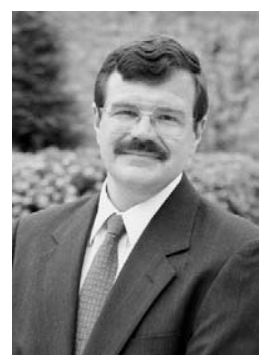

Alan R. Dennis is a Distinguished Professor of Information Systems and holds the John T. Chambers Chair in Internet Systems in the Kelley School of Business at Indiana University. He is best known for his research on collaborative technologies, but his research also examines knowledge management, innovation and the Internet. He serves as on the editorial boards of Journal of $\mathrm{Ma}$ nagement Information Systems and Journal of the Association for Information Systems and is the Publisher for MIS Quarterly Executive.

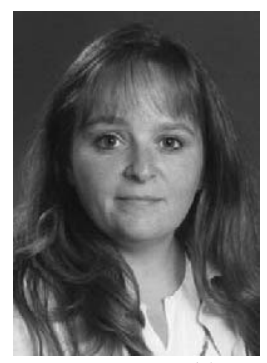

Traci A. Carte is an Assistant Professor and Price College Teaching Fellow in the MIS division of the Michael F. Price College of Business at the University of Oklahoma. She received her $\mathrm{PhD}$ from the University of Georgia. Currently, her research is focused on contingency factors related to IT implementation success. Her research has been published in Information Systems Research, Public Productivity and Management Review and in numerous national and international conference proceedings.

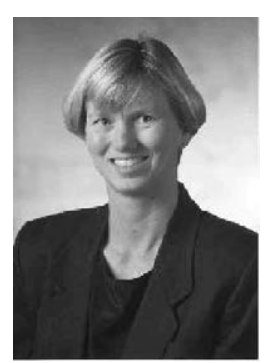

Gigi G. Kelly is an Assistant Professor at the College of William and Mary. She graduated from James Madison University with a BBA in MIS, earned her MBA from Old Dominion University and received her doctorate in MIS from the University of Georgia. Her research interests include the use of information technology to support collaborative work groups, telecommuting and the integration of information technology and organizational development. She has extensive consulting experience in MIS and some of her work has appeared in Journal of Management Information Systems, Information Systems Management, Journal of Small Group Research, Informatica and Computerworld. 